Article

\title{
Peculiarities of Prosecution and Indictment of the President of the Slovak Republic: Is Current Legal Regulation Really Sufficient?
}

\author{
Bystrík Šramel *, Peter Horváth and Ján Machyniak \\ Faculty of Social Sciences, University of Ss. Cyril and Methodius in Trnava, 91701 Trnava, Slovakia; \\ peter.horvath@ucm.sk (P.H.); jan.machyniak@ucm.sk (J.M.) \\ * Correspondence: bystrik.sramel@ucm.sk
}

Received: 10 January 2019; Accepted: 10 March 2019; Published: 13 March 2019

\begin{abstract}
In a democratic state following the principle of rule of law, every person (including state authorities) must bear a legal liability for an unlawful act committed. However, recent socio-political events in Slovakia have brought to the forefront a number of legal questions regarding the liability of the head of the state for his unlawful acts. Therefore, the aim of this paper is to examine the current legal regulation of presidential liability, which belongs to one of the controversial issues of the Slovak legal order. At the same time, it is an issue which is not a frequented subject of legal science (jurisprudence) research. Therefore, its examination and critical evaluation is necessary. However, the aim of the paper is not only to point out to the current legal regulation of this relatively unexplored legal institution, but also to show its seamy sides and to present a comprehensible and reasonable legal opinion relating to key characteristics of legal liability of the President of the Slovak Republic. The authors are of the opinion that the legal regulation of the liability of the President of the Slovak Republic is extremely brief. In addition, it contains a number of ambiguities and questions which, in the future, can cause a lot of complications in the eventual prosecution of the president. For this reason, it is more than desirable to resolve at least some of the issues referred to in the paper before the dispute arises. In every democratic state it is essential that the terms of application of legal institutions or legal provisions are understandable, clear, and certain. In the case of the institution of liability of the Slovak President, this requirement is certainly not fulfilled.
\end{abstract}

Keywords: president; Slovak Republic; prosecution; indictment; legal liability; Constitution of the Slovak Republic

\section{Introduction}

Recent socio-political events in Slovakia have brought a number of legally relevant issues related to the deliberate violation of the Constitution. One of these issues is whether the non-use of the President's appointive power could be considered as a deliberate violation of the Constitution. In particular, it was a massively mediatized case of non-appointment of the candidate to the Prosecutor-General, elected by the Parliament, and a dispute about whether the power of the president defined by the word "appoints" [Article 102 (1) of the Constitution of the Slovak Republic] should be understood as the right or duty of the president. It may be noted that the answer to this question has been offered not only by a number of lay citizens but also by the lawyers. Notwithstanding the massive politicization of the legal problem of the interpretation of the president's appointive power, it should be stressed that the question of the president's right/duty to appoint a person to office is directly related to the issue of the president's liability for committing a constitutional offense. If there is something that the president is obliged to do and the president fails to do so, he directly violates the Constitution. 
This paper is an attempt to provide a scientifically-based and well-grounded solution to many of the problems associated with the cases of presidential liability.

However, it should be stressed that it is necessary to distinguish legal liability from political liability. In this context, author Filip (2010) is of the opinion that political liability goes beyond the boundaries of the fundamental principles of the rule of law, including, in particular, the principle of the presumption of innocence, the rules of evidence, etc. The political liability of the president of the Slovak Republic and the way it is borne are enshrined in Art. 106 of the Constitution of the Slovak Republic. Under this provision, the institution of the plebiscite on the recall of a president can be regarded as the means of taking the political liability of the president. The essence of this institution is that, in the event of a serious political trespass by the president, it is possible for him to take liability directly from those who brought him to the office (citizens of the Slovak Republic), that is, the citizens may recall him from his post before the end of his term of office.

Legal liability can be established not only in the field of public law but also in the field of private law. In the field of public law, legal liability may be in the form of criminal liability, administrative liability, or disciplinary liability. Important issues of criminal liability are discussed by author Čentéš (2001). In the field of private law, it may take the form of civil liability, e.g., liability for damage, liability for infringement of incorporeal good (honour, reputation, dignity of a person). In this paper, we are dealing primarily with public law liability.

The basis for any legal liability is the violation of the obligation of the liable person. In other words, the only basis for legal liability is the commission of a delictum, offence, or wrong. Establishing the liability for committing a public-law offense is referred to as a public punishment (sentencing). The characteristic feature of this process is the fact that the entities to which liability is attributed are natural or legal persons that are in a subordinate position towards the authorities of the State. This implies the right of the state authorities to act authoritatively in case of non-observance of legal norms.

The only exception that allows the offender to extricate from (at least for a certain period of time) the liability for the offense committed is the immunity institution (the so-called exemption). The immunity is a traditional institution anchored in legal orders of all democratic countries of the world. At the same time, it represents one of the exceptions to the fundamental constitutional principle of equality defined not only in Art. 12 (1) of the Constitution of the Slovak Republic ("All human beings are free and equal in dignity and in rights. Their fundamental rights and freedoms are sanctioned, inalienable, imprescriptible and irreversible."), but also in Art. 47 (3) of the Constitution of the Slovak Republic ("All parties to any legal proceedings under paragraph 2 shall be treated equally").

Legal science understands the concept of immunity in two senses. In a broader sense, immunity is constituted by the so-called (a) indemnity and (b) immunity in a narrow sense (Filip 1997; Svák and Cibulka 2013; Palúš and Somorová 2010; Bröstl et al. 2010; Balog 2006). In the jurisprudence, it is also referred to as material immunity, internal immunity, personal irresponsibility, immunity from official acts, or freedom of speech (Filip 1997; Gřivna 2006; Pavlíček 2001; Záhora 2005). Indemnity represents the impunity of the person in relation to the expression of opinions and the voting when performing the duties of his/her office. Indemnity has the effect of exempting a person from the scope of the material law, which cannot be applied to this person to a limited extent. Indemnity means that the act of the immunity holder is not considered to be an administrative or judicial offense. In this case, impunity is permanent and has an effect even after completion of the term of office.

Immunity, in a narrow sense, is referred to by some authors as procedural immunity, procedural exception, external immunity, irresponsibility for non-official acts, or personal inviolability (Filip 1997; Gřivna 2006; Musil et al. 2003; Záhora 2005). Immunity, in a narrow, sense means the impossibility of the prosecution for the act committed. Unlike the indemnity, in this case, the immunity holder is not exempted from the scope of the material law, but from the scope of the procedural law (Code of Criminal Procedure). In such a case, the act of the holder of the immunity may fulfil the characteristics of the offense, but is excluded from the jurisdiction of the authorities responsible for 
the investigation and decision on the offense. In most cases, the consent of a competent authority (such as a parliamentary body and/or a constitutional court) is required to deal with the offense of such a person during the exercise of the office. Procedural immunity is only of a transient nature and exists only during the time of the office. After the expiration of the term of office, liability for the offense may, in principle, be established.

Recent socio-political events in Slovakia have brought to the forefront a number of questions regarding the liability of the head of the State for possible unlawful acts. This issue has become topical, in particular, as a result of the recent large-scale media publicity of cases of non-appointment of the candidate to the office of Prosecutor General and the candidates for the function of constitutional judges that were elected by the Parliament. Apart from the political aspects of these cases, it can be said that the cases were beneficial from the point of view of the professional legal public and have indicated that the current legal regulation of many issues concerning the institution of liability of the president (or his immunity) is imperfect and raises a great deal of questions. In this paper, we want to take a closer look at legal regulation the president's liability in the Slovak legal order, point out the problematic aspects, and try to propose possible solutions to the existing situation.

The aim of the paper is to examine the current legal regulation of presidential liability, which belongs to one of the controversial issues of the Slovak legal order. At the same time, it is an issue which is not a frequented subject of legal science (jurisprudence) research. Therefore, its examination and critical evaluation is necessary. However, the aim of the paper is not only to point out to the current legal regulation of this relatively unexplored legal institution, but also to show its seamy sides and to present comprehensible and reasonable legal opinion relating to key characteristics of legal liability of the president of the Slovak Republic. The aims of the paper also include critical evaluation of key aspects of a legal regulation of legal liability of the president of the Slovak Republic and, last but not least, the outlining/presentation of de lege ferenda proposals (postulates).

\section{General Substantive Law Issues Concerning the Legal Liability of the President of the Slovak Republic}

In the world, the way the countries regulate the legal liability of their head of state differs depending on the legal and cultural traditions, the status and powers of the president, and opinions of the society itself. However, every democratic country following the rule of law recognizes some form of presidential legal liability and regulates the procedure leading to the indictment of the head of the state. In English scientific literature this procedure is called "impeachment". As regards the liability itself, world legal science mentions five main factors that condition the emergence and outcome of presidential impeachment. They include (1) the institutional balance of power between the various branches of government; (2) the constitutional and statutory provisions for impeachment; (3) the structure of party politics; (4) presidential popularity prior to allegations of presidential wrong-doing; and (5) other factors, including the media environment, economic conditions, and international pressures (Baumgartner and Kada 2003). Besides that, to the mentioned factors that condition the emergence and outcome of presidential impeachment, the rule of law principle can be added too. We must add that the above-mentioned factors do not affect the legal liability in the same manner. Their intensity depends on the form of government, powers of the head of the state, and legal regulation as such. Additionally, many problems concerning the presidency are directly connected with the process of democratic transition in former totalitarian countries (Mihálik 2011).

In the Slovak Republic, the legal liability of the president and the manner of its bearing are stipulated in Article 107 of the Constitution of the Slovak Republic. ${ }^{1}$ In relation to the institution

1 This constitutional article has been substantially amended and supplemented by constitutional law no. 9/1999 Coll. of 14 January 1999 amending the Constitution of the Slovak Republic no. 460/1992 Coll. as amended by Constitutional Act no. 244/1998 Coll. In the original version of the Constitution of the Slovak Republic, the original legal regulation of legal liability of the President was stipulated as follows (until the entry into force of Constitutional Act no. 9/1999, 27 January 1999): 
of legal liability of the president, Article 107 of the Constitution of the Slovak Republic very briefly defines three basic aspects of the issue-for what offences the president can be held liable, in what way the proceedings against the president are run, and what legal consequences the conviction decision has. It is, of course, necessary to know the answers to these issues, since the holding of legal liability is directly dependent on the legal qualification of the act, the knowledge of the procedure, and the specific sanctions. However, it should be noted that the constitutional regulation of the above-mentioned issues of the president's legal liability in the current form is not sufficient at all and raises several questions.

Although impeachment is a rare phenomenon in European political conditions after the Second World War (Hanuliak 2009), its proper legal regulation is necessary in every democratic state following the rule of law. So, let us take a closer look at impeachment issues arising in the Slovak Republic from the Constitutional Article 107.

Already, the first sentence of Article 107 of the Constitution of the Slovak Republic states that "the President can only be prosecuted for deliberate violation of the Constitution or for treason". This provision exhaustively defines the legal grounds (the offenses) for which the President can be held liable. As far as the offenses themselves are concerned, their closer analysis will be made in another part of the paper. It should be noted that from the above-mentioned constitutional article it can be concluded that the Constitution of the Slovak Republic does not directly stipulate the institution of immunity or exemption of the president. Unlike other constitutional officials (such as MPs or judges of the Constitutional Court of the Slovak Republic), where the Constitution of the Slovak Republic states the things (cases) for which the prosecution is inadmissible, in case of the president the Constitution of the Slovak Republic only positively mentions the reasons for his prosecution. By argumentum a contrario, it can be concluded that in relation to other offenses (other than deliberate violation of constitution and treason) the president enjoys immunity, i.e., the protection from prosecution. This is also confirmed by the explanatory report to the Constitution of the Slovak Republic, which states that the purpose of Art. 107 of the Constitution of the Slovak Republic is to express the protection of the president as an important constitutional factor in a new way. ${ }^{2}$ Although this may not be the case, the first sentence of Article 107 raises a number of questions.

The first problem arises with the term "to prosecute". The term "to prosecute" is basically quite indefinite and unclear. However, the correct understanding of the meaning of this term is very important, particularly in relation to the finding of the nature of immunity of the president. Indeed, the impossibility of prosecution of unlawful acts committed by the president is a consequence of his immunity. Unlawful acts (public-law offenses) may have a mixed nature in the Slovak legal order. In light of their gravity, we recognize two basic types of offenses-administrative offences and judicial offenses (criminal offenses). In addition, a public-law offence is also the so-called "constitutional offense" (Večeřa et al. 2011). Its specific features (subject of offence and so on) will not be the object of attention in the next lines, but we will return to them in another place in this paper. As we said, it is important to know the concept of the term "prosecution". Understanding the nature or meaning of the concept of "prosecution" would, to a certain extent, be possible by examining a valid law in the field of administrative and judicial offenses, i.e., by reviewing the legislation regulating the procedure and decision-making of individual types of public-law offenses and by using the exclusionary method leading to the finding of such types of public-law offenses that are "prosecuted". However, the problem is that the Slovak law uses the concept of prosecution not only in the case of judicial offenses (criminal offenses), but also in the case of administrative offenses (e.g., the Act no. 372/1990 Coll. on misdemeanours). If it is necessary, the legislator mentions in the law the particular type of prosecution

"The President may be prosecuted only for treason. The National Council of the Slovak Republic files an indictment on the President; The Constitutional Court of the Slovak Republic decides on the indictment." It can be said that the new constitutional law has extended the scope of the President's legal liability, which is undoubtedly related to the newly established institution of direct presidential election.

2 See the explanatory report to the government draft of Constitution of the Slovak Republic, p. 13. 
(e.g., criminal prosecution, prosecution of the misdemeanour). ${ }^{3}$ Thus, in the Slovak legal system there is not only criminal prosecution, but also administrative prosecution (prosecution for misdemeanours).

Thus, the ambiguity of the constitutional concept of "prosecution" makes it unclear what the extent of immunity of the president, indirectly resulting from Art. 107, is. The Constitution of the Slovak Republic does not specify the term "prosecution" and does not mention if it means "criminal prosecution" or "administrative prosecution". The scientific literature suggests that this concept needs to be interpreted broadly and it basically agrees that the term "prosecution" includes criminal prosecution, administrative prosecution, disciplinary prosecution, as well as any other type of prosecution (Drgonec 2006; Domin 2012). However, this is only a suggestion of legal science which has no legally binding nature as it is not stipulated in any legal norm (legal regulation). The authors, in principle, point to the fact that the President has not only criminal immunity but also administrative immunity. This conclusion (the wider understanding of the term "prosecution") also indirectly stems from the fact that the legislator, in some cases, concretizes the prosecution, e.g., while in Art. 78 sect. 1 of the Constitution of the Slovak Republic, the legislator states that "a vote in the National Council of the Slovak Republic or in its committees cannot be prosecuted,...", sect. 2 of the same article already specifies that "the statements of a deputy concerning the performance of the function of a deputy presented at the National Council Of the Slovak Republic or in its body, cannot be criminally prosecuted, ... ". However, this conclusion is not entirely certain. For this reason, in certain circumstances, the uncertainty of the normative text may cause a number of problems, for example in connection with some recent changes made in relation to the immunity of the president.

In that regard, it must be pointed out that the Act no. 79/2012 Coll., amending the Act of the Slovak National Council no. 372/1990 Coll. on misdemeanours with effect from 1 March 2012, has cancelled the misdemeanour immunity of the president. Currently, the abovementioned Act stipulates that "this Act shall be used in regards the act of the natural person who committed the misdemeanour and the act committed by the President of the Slovak Republic." The constitutional absence of the exact meaning of the term "prosecution" and the resulting ignorance of the factual scope of immunity of the president, however, causes that under certain circumstances the abolition of the immunity of the president by ordinary law may be considered inconsistent with the Constitution of the Slovak Republic. That is particularly the case when it is indeed true that the concept of "prosecution" must be interpreted in a broader sense. In such a case, the administrative immunity (that is to say, the immunity in cases of misdemeanours, too) is also stipulated in the Constitution of the Slovak Republic and its abolition cannot be done just by an ordinary law. In the case of the president's misdemeanour immunity arising from the Constitution of the Slovak Republic, it is therefore necessary to make changes directly at the highest level, at the constitutional level, where a qualified constitutional majority is indeed required. In such a case, the abolition of immunity could be achieved by adding a few words to the constitutional text. Inspiration may be the text of the Czech Constitution, which in Article 65 sect. 1 states that "during his term of office, the President of the Republic cannot be arrested, criminally prosecuted or prosecuted for a misdemeanour or other administrative offense".

3 In general, administrative offences are unlawful acts that violate the rules of administrative law. Criminal offences are unlawful acts that violate the rules of criminal law. The general distinction between criminal and administrative offences in the Slovak legal order consists in: (1) Difference in concept and legal basis. While the concept of criminal offence and its two forms are defined directly in the Criminal Code, the concept of administrative offence has no legal definition; it is defined only by the theory of administrative law. (2) Difference in the scope of administrative authorities to deal with administrative offenses. While criminal offences are punishable by independent courts, administrative offences are punishable by administrative penalties imposed by administrative authorities. (3) Difference in the procedural regime of the sanctioning. While criminal offences are being sanctioned in a criminal law procedure that is codified in the Criminal Procedure Code, the procedure on administrative offences does not have a single codified legal regulation. (4) Difference in social defamation. The intensity of social defamation is more noticeable in the case of criminal offences, which is manifested both in the possibility of more intense consequences in the field of personal freedom of the individual (imprisonment) and in the secondary legal consequences of judicial sanctioning (loss of impeccability necessary to carry out certain activities or professions). 
Another related problem is the fact that from the content of the normative text it is also not clear whether the legislator wanted to grant the president the protection in case of an unlawful act by which he has committed a private-law (civil law) offence. In other words, whether it was intended to grant him civil law immunity and thus prevent the possibility of bearing civil liability (for example for causing damage or unjust enrichment). Opinions of the professional public differ on this subject. On one hand, there are assertions that the president has no immunity in this field. On the other hand, there are also claims that, to a certain extent, the President also enjoys immunity in this area. We are of the opinion that the president enjoys civil law immunity only in respect of such civil law offenses that were committed in the performance of his duties (as an official). In all other cases, the president does not enjoy immunity, since the granting of such protection to the president would be too far-reaching. It would be a very inappropriate and unjustified privilege, which, in the conditions of a material rule-of-law, would, to a great extent, deny the principle of equality. Similarly, as with Majerčák (2009), we conclude that civil liability for an act unrelated to the exercise of the office of a president is no longer limited by immunity, and if the president as a private person causes damage or unjust enrichment, civil liability can be imposed on him and compensation or redelivery of unjust enrichment can be demanded.

Another issue arises in the case of determining whether the immunity of the president relates to offenses committed when performing the function (activity) or during the performance of the function (time). In other words, another problem is the disclosure of the purpose of legal regulation of legal responsibility of the president. As Drgonec (2013) notes, if the president of the SR has legal responsibility for offenses committed when performing his duties, it may be argued that the purpose of the legal liability regulation is to define how the president should behave in his role so that he does not have to bear the legal liability. If the president has legal liability for the offenses committed during the performance of his office, it may be deduced that the purpose of regulation of legal liability of the president is to grant him immunity to all forms of illegal activity, with the exception of deliberate violation of the constitution or treason. As the above-mentioned fact is not specified in the Constitution of the Slovak Republic, let us look at the provisions of the Constitution of the Slovak Republic regarding the explicitly stipulated immunity of other constitutional officials. In the case of deputy's immunity, Art. 78 sect. 2 of the Constitution of the Slovak Republic states that "the deputy cannot be prosecuted for the statements made when exercising the function of a deputy, ...". In the case of the immunity of judges of the Constitutional Court, Art. 136 sect. 1 of the Constitution of the Slovak Republic also similarly states that "the judge of the Constitutional Court cannot be prosecuted for making decisions when performing his function ...".

It follows that the Constitution of the Slovak Republic constructs the legal liability (or immunity) of constitutional officials as responsibility for acts committed when performing their functions. We consider that this conclusion can also be applied to the institution of the president's liability. This conclusion is also highlighted by the explanatory report to Constitutional Law no. 9/1999, according to which "an institution of the President's irresponsibility for acts committed when performing his office is introduced ..." Last but not least, we can point out the sanction that can be imposed for committing constitutional offences (the loss of president's office and the ability to regain this office in the future). It is a sanction that does not have the nature of an ordinary public law sanction. It is explicitly directed at the capacity of the person in relation to the office of the president, to the performance of his office. Therefore, it must be the legal consequence of his official activities.

It should be added, however, that the above conclusion cannot be understood in a way that the president is protected only against offenses committed by him as an official. Although the immunity primarily protects the performance of the president's office, secondarily it also protects the immunity holder as a natural person. This may be justified, in particular, by the need to ensure proper protection of the performance of the president's office and non-abuse of the sanctioning of a presiding person for his public law offences as offences of a private individual. However, in practice it is very difficult to separate the president's activities as an official and the activity of the president as a private person. 
One of the related uncertainties is the determination of the duration of the president's immunity (determining the nature of the president's immunity). Is this immunity substantive or procedural? In the case of substantive immunity, the prosecution is impossible forever. In the case of procedural immunity, prosecution is impossible only for the duration of the immunity reason (that is, the function of the president). If we accepted the interpretation that the immunity of the president is exclusively of a procedural nature, two categories of acts would be created as follows: (1) Treason and deliberate violation of the Constitution, for which the president may be prosecuted by the National Council of the Slovak Republic and convicted by the Constitutional Court of the Slovak Republic during the exercise of the office, and (2) all other offenses contained in the Criminal Code (except treason), which the president may commit in his office. In this case, criminal liability may be taken only after the end of the presidential term of office, according to the Criminal Code. The punishment for committing treason by the president (under the Constitution) is exclusively the loss of the office of president and the loss of the capacity to assume this office again, while for any other offence, as compared to treason (even in petty cases), the president is punishable by a significantly stricter punishment under the Criminal Code.

This problem also arises because, unlike other constitutional officials, in the case of the president, the Constitution of the Slovak Republic does not explicitly stipulate the institution of immunity (exemption). It can be said that even the scientific literature is not completely unified in view of the nature of the president's immunity. Some experts claim that this is substantive-law immunity, but with procedural consequences (Ivor et al. 2010a, 2010b). Others take the view that in the case of the immunity of the president, the substantive law immunity amalgamates with a procedural exemption (Mencerová et al. 2013). It may be assumed that the president enjoys substantive law immunity on the grounds of performing his office. This fact is also supported by specialized literature, for example, saying that if the prosecution for acts committed when performing the function of the president were not excluded forever, the institution of immunity of the head of state would lose its justification or sense (Palúš and Somorová 2010). At the same time, however, it may be assumed that during the exercise of the function of the president, substantive law immunity overlaps with procedural immunity, taking into account, in particular, the fact that the Constitution of the Slovak Republic or any other legislation does not recognize the authority that would be entitled to grant consent to criminal prosecution of the president. In the exercise of his functions, the president is therefore totally excluded from the jurisdiction of the law enforcement agencies and cannot under any circumstances and in any case be detained or prosecuted. At the same time, the mentioned procedural consequence of the president's substantive law immunity persists even after the end of the function of the president. Thus, the procedural exemption is transferred to the "post-presidential" post-office period, of course, in relation to acts committed during the term of office of the president. It is possible to prosecute acts committed before taking office as well as acts committed after the end of presidential function, unless the punishability of some of them has ceased to exist. In this regard, it would be appropriate to note that it would be worth considering that the deliberate offense committed by the former president, and the valid conviction, be the reason for the termination of the claims granted to the former president by law. In particular, it is the lifelong drawing of a wage and lifelong provisions of protection of personal security. Unlike the Czech Republic, where special law no. 48/2004 Coll. on the safeguarding of the President of the Republic after the end of his office regulates such an option, Slovak general Act no. 120/1993 Coll., on the salary conditions of some constitutional officials of the Slovak Republic, banks on with no such option.

In connection with the impossibility of prosecuting the president, it has to be added that this fact certainly does not mean that the investigation of the crime as such is not possible (criminal prosecution in the case). However, if there is a sufficiently reasoned conclusion that the offense was committed by the president (the former president), prosecution must be terminated in accordance with $\S 215$ sect. 1 letter (d) of the Criminal Procedure Code (for the inadmissibility of criminal prosecution), as there is no authority authorized to give consent to prosecution. For these reasons, it can therefore 
be assumed that, in the case of the immunity of the president, immunity is absolute, not relative. This means that the president cannot be held responsible even after the function of the president has ceased to exist. This holds for the acts committed by the president when performing his duties (as an official) and for acts committed by the president as a private person. An important question, which should also be answered, is the question of the time or moment at which the president begins to enjoy immunity. In this respect, the starting and binding provision is the provision of Article 101 sect. 7 of the Constitution of the Slovak Republic, according to which "the elected candidate assumes the position of the President by making a promise." It can be deduced that the president's immunity does not arise when the candidate is elected by the citizens in direct elections, but only in the moment when he takes office. In practice, there could be a situation that a person was elected in the election, but for some reason he will not become president (he disagrees). In such a case, the granting of immunity would be contrary to its purpose-protection of the performance of the president's office.

At this point, it should be emphasized that the institution of immunity is always linked only to a person acting as president, which ultimately leads to the protection of the State and its functioning. At the end of his term of office, immunity as a protection of the office's performance also exists, but it has only a double reflective effect. The first one manifests itself backwards. It protects the person who held this office in the past for past deeds. A second effect also protects the undisturbed performance of the office by its bearers; it will manifest itself after its end. This is the protection against possible threats of prosecution that might occur after the end of the function (Filip 1997). The exercise of the president's function thus establishes the impunity of the president for all acts except for the acts exhaustively defined in the Constitution of the Slovak Republic. It is a permanent impunity. It should be borne in mind that, of course, this refers to acts committed in the period between the date of the president's assuming of office and the moment of the termination of his office. As we have already stated, in the case of committing an offense before taking up office as well as after the termination of his office, the prosecution after the termination of his office is in principle possible, of course, on the condition that the crime has not ceased to exist for any of the reasons set out in the relevant legislation (e.g., limitation of criminal proceedings, change of law). However, with regards to negative prescription, it should be pointed out that if the president has committed a criminal offense prior to the appointment of the president, under $\S 87$ sect. 2 letter (a) of Act no. 300/2005 Coll. of the Criminal Code, the assuming of office results in the so-called "suspension of limitation of criminal proceedings". This means that the period of time during which the person was acting as President is not counted in the limitation period. Criminal prosecution is thus possible to the same extent and under the same conditions as before the moment of assuming the position of the president by the elected candidate.

It should also be noted that the insufficient constitutional regulation of the legal liability of the president of the Slovak Republic gives rise to some other problematic issues of the nature of substantive law. Traditionally, each legal regulation of legal liability also defines the so-called "reasons" for the extinction of punishability of the perpetrator's act (Čič 2013). They include the change of the act, the effective regret, and the limitation of prosecution. In general, they are certain circumstances that arise after committing the offense, but before the valid decision on this offence by the Court. In this case, the legal theory states that their consequence is the extinction of the right of the state to punish the offender. Particularly, if the offender has not committed another offense, it is believed he has corrected himself and the perpetrator's punishment no longer needs to achieve the purpose of punishment.

The question in this context, however, is the following: Is it possible to apply the above-mentioned reasons for the extinction of punishability also to the constitutional offences of the president? First, let us look at the offence "treason". According to the Criminal Code, it is possible that the punishability of this offense becomes extinct for all the above-mentioned reasons (change of law, effective regret, and limitation of criminal proceedings). This means that if the later Act establishes that treason is not a criminal offense, its punishability becomes extinct (according to $\S 84$ of the Criminal Code). In reality, however, this case is unlikely, since the treason is historically one of the most stable and persistent delinquencies. Its removal from the legal order or content change is unlikely. A little more 
realistic is the extinction of punishability of treason because of the effective regret according to $\S 85$ of the Criminal Code (so-called general effective regret). Treason is one of the criminal offences of which punishability can be made extinct by the effective regret. ${ }^{4}$ The condition is that the perpetrator voluntarily either prevented the harmful consequence of a criminal offence or made a notification of a criminal offence to the law enforcement authority or the police force at a time when the harmful consequences of the criminal offense could still be avoided. Finally, the extinction of punishability of a treason may also occur as a result of the expiry of the limitation period, which is thirty years ( $\$ 87$ sect. 1 letter. (a) of the Criminal Code).

In all these cases, extinction of punishability of treason as a criminal offence is concerned. However, it is doubtful, whether the said criminal law institutions of extinction of punishability can also be applied to the president and his constitutional offence (treason). If so, the next question arises as follows: Can the above-mentioned institutions be applied even after the conclusion of a president's term? For example, does the limitation period pass even after his term of office expires? If so, it means that the president can be prosecuted even after the conclusion of a president's term. If not, it means that the president can only be prosecuted during his term of office. The expiry of the term of office thus has the effect that the limitation period has expired (i.e., it is less than thirty years) and its act is time-barred. Moreover, if these institutions can also be applied to the president, there is another problem in connection with the second constitutional offence of the president-deliberate violation of the Constitution. In the case of this constitutional offense, the Criminal Code does not regulate any criminal offense of deliberate violation of the Constitution (closer to this constitutional offence in another part of this paper). At the same time, this means that the constitutional offence of the deliberate violation of the Constitution does not allow its punishability to become extinct due to the above-mentioned institutions. There is no change in the law, neither effective regret nor limitation of criminal proceedings. Thus, there is a certain discrepancy between the constitutional offenses of the president, where, in one of them (treason), the president has the possibility that the offense will not be sanctioned. In the latter case (deliberate violation of the Constitution) something like that is not possible. Does this mean that a deliberate violation of the Constitution is such a serious offense that it cannot come to the extinction of punishability? This is certainly not the case. The only possible explanation is that, in fact, the legislator did not take into account the wider context of the issue; he was inconsistent. The starting point of this situation seems to be just another normative activity of the legislator in this area or the specific decision-making activity of the Constitutional Court of the Slovak Republic.

In addition, other problems of a substantive law nature are also considered. Interesting is the question of the extinction of punishment. Is it possible for the president to think of any grounds for extinction of punishment? The only sanctions for the constitutional offence of the president are the loss of the office of president and the loss of the capacity to assume this office again (Article 107 of the Constitution). These are sanctions, the purpose of which is to ensure that a person who has already disreputed the office of a president and endangered or infringed the interests of the state can no longer hold this office. According to the Criminal Code, the extinction of punishment may occur as a result of forgiveness or mitigation of the punishment ( $\S 89$ of the Criminal Code) or as a result of a limitation of the execution of a sentence ( $\$ 90$ of the Criminal Code). Since the legal effects of both sanctions (both the loss of the office of a president and the loss of capacity to assume this office) occur at the time of the valid judgment of conviction, limitation of the execution of the sentence as a reason for the extinction of the punishment is virtually impossible. Thus, we can think of the remission of the punishment that could theoretically be applied by the new president in relation to the former president

4 On effective regret see closer Jozef Čentéš, Účinná l'útost' pri daňových trestných činoch v SR a v ČR. Nové jevy v hospodářské kriminalitě ve světle reformy trestního práva (Active repentance at tax offenses in the Slovak Republic and in the Czech Republic. New phenomena in economic crime in the light of the reform of criminal law), Brno: Masarykova univerzita, (Čentéš 2011, pp. 6-17). 
sentenced by the Constitutional Court of the Slovak Republic. However, this situation is very difficult to imagine and it may be thought that the legislator did not even think or imagine something like this. We are therefore inclined to think that the extinction of punishment in the case of the constitutional offence of the president is absolutely impossible. The intent of the legislator is simply to prevent a person from being able to re-assume the office in the future.

Herein, we should note that determining the legal liability is possible only in cases that are exhaustively defined in the Constitution of the Slovak Republic. It is not possible to interchange the political reasons with legal reasons and abuse them for the purposes of taking legal liability. Legal liability, its origins, and its consequences are always conditional upon the existence and respect of specific legally relevant facts. Taking legal liability is possible just then if it is proved without reasonable doubts that a certain act has been committed and that the act is committed by the president and that his act fulfils all the constituent elements of the constitutional offence of the president. Any other facts that are either objectively groundless or have the character of arguments of political competition cannot be used in the taking of the President's legal liability. However, in this respect, the constitutional regulation of legal liability is not sufficient. The problem is, in particular, the absent definitions of the basic legal grounds for taking the president's legal liability. For this reason, further attention will be given to the individual legal grounds (constitutional offences), the result of which is the legal liability of the president.

\section{Analysis of Individual Constitutional Offenses of the Slovak President}

Under the Article 107 of the Constitution of the Slovak Republic, the first legal cause that establishes the legal liability of the President is "treason". In general, treason as an offense is recognized in every legal order irrespective of the form of government (democratic or authoritative). Treason is first and foremost a crime against the State, which has been persecuted since birth of the first states (Orr 2002). In the Slovak Republic, this is a term that is also known to the Slovak legal order and it is recognized by the criminal law branch. As a consequence of the fact that this institution is also recognized by the Constitution of the Slovak Republic, it is also a constitutional institution. Since it is a term used in the law of the highest legal force, it is necessary to know its content. However, there is a problem here. The Constitution of the Slovak Republic does not define what the treason is and how it manifests itself. The only reference to this term and its definition is provided by $\S 74$ sect. 1 of the Act no. 38/1993 Coll. on the organization of the Constitutional Court of the Slovak Republic, on the proceedings before it and on the status of his judges, which states that the Constitutional Court of the Slovak Republic is bound by the Criminal Code when deciding on the indictment of the National Council of the Slovak Republic for treason.

It follows from this that the legislator left the question of defining the term of treason to an Act with a legal force lower than the Constitution of the Slovak Republic, which means that the president may be prosecuted to the same extent as the offense defined in $\S 311$ of Act no. 300/2005 Coll. of the Criminal Code. According to the mentioned provision, the constitutional offence of treason lies in the fact that the perpetrator (explicitly a citizen of the Slovak Republic, in this case the president of the Slovak Republic), in association with a foreign power or a foreign agent, commits the criminal offence of seditious conspiracy against the Slovak Republic ( $\$ 312$ of the Criminal Code), terror ( $\$ 313$ and 314 of the Criminal Code), destructive actions ( $\S 315$ and 316 of the Criminal Code), or sabotage (§ 317). It should be added that under $\S 133$ sect. 1 of the Criminal Code a foreign power means foreign States and their military or other groupings represented by their organizations and bodies; particularly, by persons carrying out intelligence activities, military officials, diplomats, and other civil servants. On the contrary, a foreign official shall mean a natural person or a legal entity which, although not being a body or a representative of a foreign State, nevertheless has an important influence in his state or in international relations because of his political, economic, or social status.

We have already mentioned that some legal problems are raised by the first cause for the taking of the president's liability (treason). However, the second cause is even worse or more complicated. 
Under the Article 107 of the Constitution of the Slovak Republic, the president may be prosecuted also for "the deliberate violation of the Constitution". Unlike treason, in connection with which the Act no. 38/1993 Coll. at least tries to provide a response to the concept or meaning of this term by reference to the legal qualification specified in the Criminal Code, in the case of deliberate violation of the Constitution, such a reference is totally absent. It can be said that the absence of a reference to the definition of deliberate violation of the Constitution is also quite natural and obvious, since such a violation is not recognized in any legal branch of the Slovak legal order and there is no such a criminal offense in the Criminal Code. It would therefore be entirely justified if the legislator had, at least in this case, defined a constitutional offense of deliberate violation of the Constitution. However, he does not do that.

The question at issue concerning the second cause for taking the president's liability is also the question of causation. The Constitution of the Slovak Republic explicitly states that the prosecution of the President requires a deliberate act, which violates the Constitution. However, the Constitution of the Slovak Republic not only does not define when the offense is committed deliberately, but also does not refer to the application of a specific substantive law regulation containing the definition of a deliberate causation. Therefore again, we must find help in other branches of public law. It may be assumed that, for the needs of the Constitution, the legislator did not intend to establish an institution of causation that is different from the institution of causation defined in other branches of public law, which is also constitutional law. If we compare the definition of intention in administrative law and criminal law, we find that they are very similar. ${ }^{5}$ They differ only in the scope (quality) of the prescribed unlawful act and the object that must be violated or endangered in the given case. The above definitions could also be applied analogously to the definition of intent for the purpose of the constitutional offence of deliberate violation of the Constitution by the president.

The most serious problem of this constitutional offence of the president is the question of what the Slovak constitution actually is. It is dubious where the Slovak constitution begins, where the Slovak constitution ends, and what the content of the Slovak constitution is. So, it is the polylegal character of the Slovak Constitution that can be the most serious problem of deliberate violation of the Constitution. It can be assumed that the Slovak constitution cannot be understood as a single legal act called "the Constitution of the Slovak Republic". Other legal norms of the highest legal force can also be included in this term. They are the following: Charter of Fundamental Rights and Freedoms no. 23/1992 Coll., Constitutional Act No. 227/2002 Coll. on State Security at the Time of War, State of War, State of Emergency, and State of Crisis, Constitutional Act No. 357/2004 Coll. on Protection of Public Interest during Performance of Public Function Officials, Constitutional Act No. 397/2004 Coll. on the cooperation between the government and the National Council in EU-related matters, and Constitutional Act No. 254/2006 Coll. on the establishment and activity of the Committee of the National Council of the Slovak Republic. It should be added that there are also constitutional acts regulating the borders. However, they cannot be regarded as part of the constitutional system stricto sensu.

\section{Procedural Problems of Legal Liability of the President of the Slovak Republic}

As can be seen from the previous text, the substantive law aspects of the president's liability entail an extraordinary number of questions. The procedural aspects of the analysed issue seem to be a little better, but there are a number of uncertainties in this area too. These include, in particular, the

5 Under $\S 15$ of the Act no. 300/2005 Coll. Criminal Code an intentional criminal offence is that where the offender (a) acting in a manner defined in this Act, had the intent to infringe or prejudice an interest protected under this Act, or (b) was aware that his act was likely to cause such infringement or prejudice, and was prepared to accept that consequence, should it occur. Under $\S 4$ sect. 2 of the Act no. 372/1990 Coll. on misdemeanors an intentional misdemeanor is that where the offender (a) acting in a manner defined in this Act, had the intent to infringe or prejudice an interest protected under this Act, or (b) was aware that his act was likely to cause such infringement or prejudice, and was prepared to accept that consequence, should it occur. 
process of taking legal liability and the related question of the possibility and appropriateness of the application of some criminal law institutions. The Constitution of the Slovak Republic, in this respect, contains only the answer to whom, and under what conditions, can file the indictment against the president and what subject decides on the indictment. We do not have more details in the Constitution of the Slovak Republic and the Constitution of the Slovak Republic does not contain any enabling clauses stating that the details of the prosecution proceedings on the president of the Republic are to be regulated by a special law.

The basis for the clarification of nature of the proceedings on the prosecution of the president of the Slovak Republic is $\S 74$ sect. 2 of Act no. 38/1993 Coll. on the organization of the Constitutional Court of the Slovak Republic, on the proceedings before it, and on the position of his judges, according to which the provisions of the Criminal Procedure Code (i.e., Act no. 301/2005 Coll.) shall be applied accordingly. Thus, we can conclude that the legislator connects the proceedings on the prosecution of the president with the criminal law branch. However, on the basis of a number of specificities that characterize the explored process, it can be said that this is not an ordinary type of criminal procedure. Even though the Code of Criminal Procedure does not stipulate it directly, it can be assumed that the prosecution proceedings against the president of the Slovak Republic can be attributed to the so-called specific ways of criminal proceedings explicitly defined in the seventh chapter of the Criminal Procedure Code (e.g., proceedings against juveniles, proceedings against a runaway, etc.). The specific ways of criminal proceedings are some deviations from the classical criminal procedure. They are characterized by the rule that general provisions on criminal proceedings are to be applied only if the regulation of a special way of proceeding does not stipulate anything else. Due to the very specific features of proceedings on indictment against the president, this rule can also be applied to this procedure.

As already mentioned, the proceedings on indictment against the president of the republic are procedurally of criminal nature. For this reason, it has many points of contact with general criminal proceedings and is governed by a number of common rules, principles, or institutions applicable to general criminal proceedings. As the Constitutional Court is bound by the Criminal Procedure Code, we can deduce that, similarly to the ordinary criminal proceedings, criminal proceedings on indictment against the president must respect all the fundamental principles of criminal proceedings. The basic principles that can be highlighted in relation to the president are the following: the principle of prosecution only on the legal grounds and in a manner provided for under the Act, the principle of presumption of innocence, the principle of the right of defence, the search principle, the principle of finding the facts without reasonable doubt, the public's principle, and the principle of contradiction.

There are a number of significant facts arising from these principles. In the first place, the president cannot be prosecuted unreasonably. The reason for his prosecution may only be the reasonable suspicion of commission of a defined constitutional offense and it is necessary to observe the procedure laid down in the Criminal Procedure Code (of course, taking into account the specifics of the proceedings). It is absolutely inadmissible to prosecute the president on the grounds of political views or increasing voters' preferences. Furthermore, like any other person against whom the prosecution is pursued, the president is deemed innocent until the court pronounces the guilt by the verdict of his guilt. This means that the president can be considered a perpetrator of treason or in deliberate violation of the Constitution only if it is proved to him that the act was committed and the act was committed by the president in the form of a deliberate causation. Until the court makes such a statement, the president cannot be described as an offender. Of course, like any other person, the president has the right to a defence. In this connection, Yordanova claims that right of defence is one of the major rights of every person who has been formally charged with a crime. It relates to the president, too. His defence should also include personal defence, official defence, and defence by a defence attorney (Yordanova 2012). The right of defence is a major part of procedural rights which are accepted by many international documents and international or regional organizations. In the last decades the EU has made steps towards strengthening basic procedural rights, including a right of defence (Klimek 2015). 
So, following these facts, in principle, it can be assumed that the President can defend all by himself or by a defence attorney.

It should also be noted that since the proceedings on indictment against the president of the republic are a special form of criminal proceedings, the investigators of the act will, of course, play an important role. Who specifically has the authority and duty to investigate a presidential offense that is not known? Anyone who is an investigator of the act must, however, with the same care, clarify the circumstances bearing evidence both of his guilt and his innocence and, in both directions, develop evidence in such a way that it enables the court to make a fair decision. Although it is possible to assume that this obligation also applies to the prosecutor himself-the National Council of the Slovak Republic, it is very difficult to imagine in practice that the National Council of the Slovak Republic, composed of representatives of political parties (trying to reach a judgment of conviction), will submit to the court evidence in favour of the president. Both the investigators and the court itself must act in such a way that the facts of the case are found without any reasonable doubts and in the extent necessary for the decision. This is of great significance to the president, since it is inadmissible to be held guilty if his case has not been properly elucidated and there are reasonable doubts about his guilt.

Furthermore, it should be emphasized that, as in the case of ordinary criminal proceedings, even in the case of an indictment proceedings against the president of the republic, the hearing of the case before the court should be conducted in public. The public hearing of the case is even more urgent here as it is about discussing the deed of a president directly elected by citizens and also responsible to citizens. Therefore, citizens must have the right to consider whether the proceedings against the president are being conducted properly, whether the president does not abuse his or her influence and, of course, that his procedural rights are also respected. The proceedings are also characterized by the fact that not only the National Council of the Slovak Republic, but also the president, must be allowed to propose and submit evidence in support of his claims and to acquaint himself with the evidence submitted by the National Council of the Slovak Republic. At the same time, the president must be guaranteed the right to comment on all the evidence and on all the facts of his blame.

Besides the common features, however, the proceedings on indictment against the president of the republic are different from the traditional criminal procedure in many aspects. The most striking differences can be seen, in particular, with regard to the subjects of the proceedings, i.e., agents having and exercising their own influence on the course of the procedure, who are granted certain procedural rights and procedural obligations for that purpose. According to criminal law theory, the traditional subjects of criminal proceedings are such subjects as law enforcement authorities (public prosecutor and the policeman), the Court (in particular the District Court), the person against whom the prosecution is conducted, the persons with rights of defence and other entities (Čentéš et al. 2012). All of these entities have an irreplaceable place in ordinary criminal proceedings and the participation of the majority of them in criminal proceedings is necessary, in principle. However, in the case of indictment proceedings against the president of the Slovak Republic, this does not apply and there are some differences or specificities. Many of the entities mentioned in this case do not appear here and are replaced by special entities. This is particularly striking in court proceedings where, the role of traditional parties, the plaintiff and the defendant, is not played by the traditional subjects of traditional criminal procedures. A particular feature is also the authority which decides and handles the dispute itself between the plaintiff and the defendant (the court).

As regards the plaintiff himself, in the case of indictment proceedings against the president of the Slovak Republic, the plaintiff under Article 107 of the Constitution of the Slovak Republic is the National Council of the Slovak Republic. As can be seen, while in the case of classical criminal proceedings the plaintiff is the public prosecutor, in the case of proceedings against the president, the plaintiff is the representative body-the body representing the citizens of the Slovak Republic. In this respect, the peculiarity of the proceedings against the president lies in the fact that, while in ordinary criminal proceedings only the prosecutor is entitled to file an indictment, in the case of an indictment against the president there is an exception; the indictment is filed by a person significantly different 
from the classical public prosecutor. This also means a further difference. In the case of ordinary criminal proceedings, the indictment is a monocratic decision, i.e., it depends on the assessment of the prosecutor himself, whether the matter is "mature" to the prosecution or not. On the other hand, filing an indictment against the president is a collegiate decision, i.e., a decision that results from the majority of the votes cast in the collegiate body (parliament). Article 107 of the Constitution of the Slovak Republic explicitly states that the filing of the indictment by the National Council of the Slovak Republic is possible only if a three-fifths majority of the votes of all deputies is reached. If this majority is not reached, the filing of the indictment to the president is not taken into consideration. At this point it can be stated that a legal theory considers this provision of the Constitution to be a lex specialis to the general provision of Art. 130 sect. 1 letter (a) of the Constitution of the Slovak Republic, under which at least one fifth of the members of the National Council of the Slovak Republic may file a motion to initiate proceedings.

Regarding the initiation of the filing of an indictment against the president by the National Council of the Slovak Republic, it should be noted that, while in the ordinary criminal proceedings the filing of an indictment by the public prosecutor is usually initiated by a policeman's motion, ${ }^{6}$ in the case of indictment proceedings against the president of the republic, the question of the person entitled to file a motion for filing the indictment is somewhat disputed. Under $\S 106$ sect. 1 of Act no. 350/1996 Coll. on the Rules of Procedure of the National Council of the Slovak Republic, the motion for indictment of the president of the Slovak Republic for deliberate violation of the Constitution or for treason may be submitted to the National Council of the Slovak Republic by at least one fifth of the deputies. However, the Constitution of the Slovak Republic does not specify, in any of its provisions, the number of members of the National Council of the Slovak Republic who are entitled to submit such a proposal. As Drgonec points out in this case, the apparent inconsistency of $\S 106$ sect. 1 of Act no. 350/1996 Coll. with Art. 107 of the Constitution of the Slovak Republic is the reason for the application of the constitutional order stipulated in Art. 152 sect. 4 of the Constitution of the Slovak Republic, according to which the interpretation and application of generally binding legal regulations, in this case the Act on the Rules of Procedure of the National Council of the Slovak Republic, must be in accordance with the Constitution of the Slovak Republic. As § 106 sect. 1 of the Act no. 350/1996 Coll. in accordance with Art. 107 of the Constitution of the Slovak Republic cannot be applied, the regulation of $\S 106$ sect. 1 should be qualified as an obsolete legal norm (Drgonec 2012). This implies the conclusion that the National Council of the Slovak Republic may take decisions on filing an indictment against the president of the republic also on the basis of a motion submitted by one deputy. In practice, however, it can be assumed that the filing of an indictment is initiated by several deputies (a group of deputies). This was also in the case of the first proposed indictment against the president in 2013.

The procedure in cases of filing a deputy's motion for the filing of an indictment is stipulated in $\S 106$ sect. 2 of the Act no. 350/1996 Coll. on the Rules of Procedure of the National Council of the Slovak Republic, under which the motion for the indictment of the president of the National Council of the Slovak Republic shall be, without undue delay, assigned to the Constitutional Committee for discussion and sent to the president of the republic and to the government. The chairman of the National Council, within 30 days from the day when he has received a motion for indictment against the president of the republic, shall convene a meeting of the National Council of the Slovak Republic in which the motion for the indictment of the president of the republic shall be discussed and decided. The president of the republic must be invited to this meeting of the National Council of the Slovak Republic and must be able to comment on the motion for his indictment and to take part in the debate.

As we have already mentioned, filing an indictment in the case of a prosecutor is a monocratic decision and, in the case of the National Council of the Slovak Republic, it is a collective decision. Notwithstanding the obvious fundamental differences in the nature of these decisions, it is worth

6 Comp. § 209 sect. 1 of Slovak Criminal Procedure Code. 
pointing out their common feature or assumption that in no case can the indictment be the result of an arbitrary decision by the competent authority. Much like the public prosecutor can only file an indictment if the results of the investigation sufficiently justify bringing the accused to court, even in the case of the National Council of the Slovak Republic, the indictment can only be filed on the basis of the existence of such evidence that sufficiently justifies the filing of an indictment. Just as the prosecutor is not bound by the motion of a police officer for filing an indictment, nor is the National Council of the Slovak Republic bound by the motion of a deputy (group of deputies) for filing an indictment against the president. It is therefore necessary that a deputy (group of deputies) in his proposal proves, without reasonable doubts, that a particular act is in fact a constitutional offence and that the constitutional offence has been deliberately committed by the president. If this does not happen, the National Council of the Slovak Republic cannot accept the motion and decide on filing the indictment. If, however, it still happened, the court could, in the context of the preliminary hearing of the indictment, be able to take, in accordance with $\S 244$ of the Code of Criminal Procedure, one of the decisions stipulated in the Code (e.g., to stop the prosecution). It should be noted that the motion for an indictment against the president of the republic is approved by the National Council of the Slovak Republic, under $\S 106$ sect. 3 of the Act no. 350/1996 Coll. on the Rules of Procedure of the National Council of the Slovak Republic, in a secret ballot. This solution practically ensures that every deputy can vote on the motion according to his or her conscience and conviction and without having to comply with the instructions coming from the party directorate.

Another peculiarity of the proceedings against the president relates to a person who has the power to decide on the indictment, i.e., the arbitrator of a constitutional dispute. Whereas, in the case of ordinary criminal proceedings, the District Court is, in principle, a criminal court (a body competent in the first instance), in the case of proceedings against the president, it is the Constitutional Court of the Slovak Republic. The Constitutional Court of the Slovak Republic does not take decisions in the senate but in the plenum. The plenum is an organizational component of the Constitutional Court of the Slovak Republic, which participates in the exercise of the decision-making power of the Constitutional Court itself. Under $\S 2$ sect. 4 of the Act no. 38/1993 Coll. the plenum of the Constitutional Court is constituted by all 13 judges of the Constitutional Court. It should be noted that the Constitutional Court is competent to take decisions in the plenum and to adopt resolutions if at least seven judges are present for the hearing and decision-making. The plenum of the Constitutional Court adopts resolutions by an absolute majority of all judges. This means, in practice, that at least seven votes are needed to make a decision. If only seven judges are present, all judges present must vote for the adoption of a decision. If this majority is not reached, the proposal will be rejected. In connection with the proceedings on the indictment against the president of the republic, under $\S 74$ sect. of the Act no. 38/1993 Coll. on the organization of the Constitutional Court of the Slovak Republic, on the proceedings before it, and on the status of his judges, the Constitutional Court takes decisions in the form of a judgment (as well as the district court in ordinary criminal proceedings). It is a form of decision in the matter of merit (a meritorious decision) issued by the Constitutional Court of the Slovak Republic, not only when the president is found guilty, but also if he is acquitted of the charges. At the same time, it is the only case in which the Constitutional Court of the Slovak Republic takes decisions in the form of a judgment (in other cases, the Constitutional Court of the Slovak Republic takes decisions either in the form of a resolution or a finding).

As regards other criminal-law institutions, it should be emphasized that, as in the case of classical criminal proceedings where the burden of proof is borne by the prosecuting prosecutor, even in the case of prosecution against the president, the burden of proof is on the plaintiff, in this case the National Council of the Slovak Republic. If the National Council of the Slovak Republic fails to do so and it fails to prove guilt of the president without reasonable doubts, the Constitutional Court of the Slovak Republic must pronounce a verdict of not guilty.

Another issue that comes to mind in the context of the prosecution of the president is the question of whether it is possible to use the traditional criminal means of securing individuals for the purposes 
of criminal proceedings, ${ }^{7}$ the means of securing matters of importance for criminal proceedings ${ }^{8}$, and information and technical means or means of operative-search activity ${ }^{9}$ against the president in the case of prosecution for defined constitutional offenses. As the proceeding on the indictment against the president can be regarded as a criminal proceeding, although of a special nature, it can be concluded that the use of these means is not, in principle, excluded. This is mainly due to the general purpose of criminal proceedings, which is to find out if the offense has been committed without reasonable doubt and, if so, to find out the offender and to impose a punishment under the law. In order to achieve this goal, it is of course necessary for the court, in particular, to have certain persons (defendant, witnesses, etc.) whose presence is necessary for the purpose of the criminal proceedings, or things that can help clarify the case. In addition, the complexity of the case may require the application of several institutions serving to provide information relevant to criminal proceedings. The common goal of all the above means is to obtain as much evidence as possible for the proper clarification of the case and the issuing of a fair decision, even in relation to the president. The nature of the constitutional offenses of the president and the specific nature of the proceedings itself, of course, imply that several of those means will not be used in the prosecution proceedings. At the same time, however, the use of some of them will be necessary and required for the proper discovery and investigation of the matter. If we take into account, for example, a treason, it can be committed in a relatively sophisticated way, without the evidence directly demonstrating the guilt of the president. Particularly demanding, can be whether the president has committed acts in connection with foreign powers and foreign officials. In this case, it may, therefore, be more than desirable to use some information-technical means or means of operative-search activity.

An important procedural question is whether, in the case of a Constitutional Court judgment, it is possible to apply any legal remedy. This is an important issue because, as in ordinary criminal proceedings, even in the prosecution of a president, there may be mistakes. The Constitution of the Slovak Republic in relation to the prosecution of the president does not say anything about whether and who can examine the decision of the Constitutional Court of the Slovak Republic on the indictment of the president of the republic. Similarly, neither Act no. 38/1993 Coll. on the organization of the Constitutional Court of the Slovak Republic, on the proceedings before it and on the status of his judges, which contains a brief provision on the prosecution of the president of the republic in the Constitutional Court of the Slovak Republic, says nothing about legal remedies. There are several remedies in the Criminal Procedure Code, some of which are of the nature of ordinary legal remedies (complaint, appeal, statement of opposition), others are of the nature of extraordinary legal remedies (reversal of the final decisions in the preliminary proceeding, review, reopening of proceedings). However, it is questionable whether the provisions of the Criminal Procedure Code on legal remedies can also be applied to the indictment proceedings against the president of the republic.

In this regard, it can be noted that proceedings before the Constitutional Court of the Slovak Republic are generally characterized by a number of elements which are common to other proceedings (e.g., criminal or civil), but at the same time it is characterized by several differences. Such divergences also include differences in the examination of decisions issued by the Constitutional Court of the Slovak Republic. It should be noted that the Constitution of the Slovak Republic in Art. 133 explicitly states that a decision of the Constitutional Court of the Slovak Republic cannot be appealed. An exception to this rule is granted to no type of proceedings before the Constitutional Court of the Slovak Republic.

7 It includes the following means: Summons, bringing in, witness securing, detainer, restriction of the personal freedom of a person caught up in a crime, arrest warrant, international arrest warrant, European arrest warrant, and detention.

8 This includes the following: Issuing, delivery of a thing, storage and delivery of computerized data, taking away a thing, taking over of a secured thing, securing of funds, securing of book-entry securities, home inspection, inspection of other spaces and land, personal inspection, detention of consignments, opening of consignments, replacement of a content of a consignments, controlled delivery, and fictitious transfer.

9 These include: Tracking people and things, making picture, audio or video-audio recordings, wiretapping and recording of telecommunication operations, agent, and comparing data in information systems. 
It follows that any decision given in the proceedings before the Constitutional Court is final, binding, and unchangeable. This conclusion also results from the fact that the Constitutional Court of the Slovak Republic is constituted as the only state body; therefore, it is a one-degree authority. There are no other bodies that can check the correctness of its decision.

In this regard, however, it must be noted that the impossibility of the president to challenge a judgment of the Constitutional Court of the Slovak Republic in the matter of his constitutional offense, to a certain extent, may be contrary to some international documents. For example, under article 2 of Protocol No. 7 to the Convention on the Protection of Human Rights and Fundamental Freedoms, "everyone convicted of a criminal offence by a tribunal shall have the right to have his conviction or sentence reviewed by a higher tribunal." Similarly, article 14 sect. 5 of the International Covenant on Civil and Political Rights states that "everyone convicted of a crime shall have the right to his conviction and sentence being reviewed by a higher tribunal according to law." As we can see, both legal documents stipulate a right to appeal a criminal conviction which is ranked by the legal science among the major human rights instruments (Book 2011; Safferling 2012). Moreover, article 13 of the Convention for the Protection of Human Rights and Fundamental Freedoms, provides for the right of appeal, notwithstanding that the violation has been committed by persons acting in an official capacity. However, as we have already mentioned above, the absence of a higher court in the case of the Constitutional Court of the Slovak Republic makes it impossible to fulfil the above-mentioned international requirements.

\section{Conclusions}

It can be concluded that the legal regulation of the liability of the president of the Slovak Republic is extremely brief. In addition, it contains a number of ambiguities and questions which, in the future, can cause a lot of complications in the eventual prosecution of the president. For this reason, it is more than desirable to resolve at least some of the issues referred to in this paper before the official disputes arise. In every democratic state following the rule of law it is essential that the terms of application of legal institutions or legal provisions are understandable, clear, and certain. In the case of the institution of liability of the president, this requirement is certainly not fulfilled.

Current legal solutions regarding the legal qualification of the constitutional offence of treason cannot be considered correct. If a new institution is established in the legal regulation of the highest legal force, which in addition can significantly affect the status of a constitutional official, it is desirable that this institution is also constitutionally defined. As a result of the indicated legal situation, the legal certainty of the president is greatly reduced, especially in relation to the reasons for the conclusion of his office as a qualified constitutional majority is not required to change the concept of treason. Thus, treason (the way of its defining) as a reason for bearing legal responsibility can easily become an instrument of political struggle or a means of indirect coercion and influence on the activity of the president. At the same time, it is important to note that the shortcomings of the current legal regulation of the constitutional offence are also of a legislative and technical nature, since the Constitution of the Slovak Republic does not contain any authorization or reference (a blanket legal norm) stating that the details of the offence will be regulated by the law of a lower legal force. Thus, in this case, treason can be regarded as a constitutional offense, but without a constitutional definition or a constitutional mandate to define it by an act with a lower legal force.

It can be said that we cannot agree with the legislator's view that it is inappropriate to create different concepts of treason, one for the president and other for citizens. First of all, a presidential offense, since it is stipulated directly at the constitutional level, cannot be considered as a classic case or type of unlawful act. The president, by his status and activity, fundamentally differs from ordinary citizens. As a constitutional body, he performs irreplaceable tasks on behalf of the state, participates in the proper conduct of other state bodies, and has rights that are not granted to the ordinary citizen. In the case of ordinary citizens, the Constitution of the Slovak Republic does not introduce any specific offenses and does not regulate their tasks or duties. An ordinary citizen cannot commit a constitutional offense; he is responsible for unlawful conduct having the character of a 
criminal offense or administrative offense. For these reasons, it is totally justified, and even natural, if the Constitution of the Slovak Republic regulates in a specific way a certain offense, whose designation (by coincidence) is also used by another public law branch (criminal law). In many cases, constitutional institutions cannot be identified with other similar institutions, having their foundations also in other branches of public law.

Furthermore, it is extremely complicated to provide a clear answer for what the deliberate violation of the Constitution as a constitutional offence of the president means. Logically, it can be assumed that it means behaviour of the president which is at odds with the constitution and the constitutional laws. Some authors consider that the violation of the Constitution includes any conduct different from behaviour which is explicitly regulated not only in the Constitution of the Slovak Republic and in constitutional laws, but also in international conventions, which are the sources of constitutional law under Art. 7 or Art. 154c sect. 1 of the Constitution of the Slovak Republic. However, although the interpretation of the concept of violation of the Constitution should be as mentioned, the scope of conduct that is already considered incompatible with the constitution is not obvious. Is the reason for taking legal liability also a less serious violation of the Constitution, or only a serious violation of the Constitution? The sanction for a violation of the Constitution by the president is rather strict and it is questionable whether the legislator's intention was to sanction the president, even in the case of the low degree of gravity of the president's unconstitutional behaviour. Since the Constitution and the explanatory report do not specify the degree of seriousness (gravity) of the presidential offense, it may be assumed that any unconstitutional conduct of the president may establish his legal responsibility. This conclusion is also supported by the scientific literature. Again, however, it must be stated that these are only the legally non-binding opinions of legal science and the answer to what extent of the unconstitutional act is necessary, or what criteria for its definition are, can be given only by the legislator or by the Constitutional Court of the Slovak Republic within the frame of the interpretation of the Constitution of the Slovak Republic proceedings.

Besides the aforementioned issues, current legal regulation of prosecution and indictment of the president of the Slovak Republic also implies many procedural issues. Current legal regulation does not specify who specifically has the authority and duty to investigate a presidential offense. The legal regulation says nothing about the consequences in the case of a not guilty verdict. In this respect, it might be considered that, in the case of a not guilty verdict, the Constitution of the Slovak Republic stipulated the same legal consequences as in the case of a failed plebiscite on the recall of a president - the dissolution of the National Council of the Slovak Republic by the president. The reasons would be similar to those of the said institution. An important procedural question is whether, in the case of a Constitutional Court judgment, it is possible to apply any legal remedy.

On the basis of analysis, it can be concluded that, under the current legal regulation, the legal remedy against a meritorious decision on indictment against the president (judgment) is not admissible. This applies both to bringing an ordinary remedy (appeal) and to an extraordinary remedy (review, retrial). With regards other types of remedies, we can think of legal remedies against the decisions of the court regulating the course of the proceedings-resolutions. In this case, in principle, complaints can be made. In this regard, however, it must be noted that the impossibility of the president to challenge a judgment of the Constitutional Court of the Slovak Republic in the matter of his constitutional offense, to a certain extent, may be contrary to several international law documents.

\section{Regulations}

Constitution of the Slovak Republic no. 460/1992 Zb.

Act no. 300/2005 Coll.-Criminal Code of the Slovak Republic

Act no. 301/2005 Coll.-Criminal Procedure Code of the Slovak Republic

Draft of the Deputy of the National Council of the Slovak Republic J. Drgonec for the Issue of the Constitutional Act amending the Constitution of the Slovak Republic no. 460/1992 Coll. 
Statement of the Government of the Slovak Republic on the Draft of the Deputy of the National Council of the Slovak Republic J. Drgonec for the Issue of the Constitutional Act amending the Constitution of the Slovak Republic no. 460/1992 Coll.

Decision of the Constitutional Court no. I. ÚS 39/93

Decision of the Constitutional Court no. I. ÚS 7/96

Decision of the Constitutional Court no. I. ÚS 61/96

Decision of the Constitutional Court no. PL. ÚS 14/06

Decision of the Constitutional Court no. PL. ÚS 4/2012

Author Contributions: Conceptualization, B.Š.; Data curation, P.H. and J.M.; Formal analysis, B.Š. and P.H.; Funding acquisition, B.Š.; Investigation, P.H. and J.M.; Methodology, B.Š. and J.M.; Project administration, B.Š.; Resources, P.H. and J.M.; Validation, J.M.; Visualization, P.H.; Writing—original draft, B.Š.; Writing一review \& editing, B.Š., P.H. and J.M.

Funding: This research received no external funding.

Conflicts of Interest: The authors declare no conflicts of interest.

\section{References}

Balog, Boris. 2006. Imunita poslancov Národnej rady Slovenskej republiky (Immunity of members of National Council of the Slovak Republic). Právny Obzor 89: 244-64.

Baumgartner, Jody C., and Naoko Kada. 2003. Presidential Impeachment in Comparative Perspective. London: Greenwood Publishing Group.

Book, Jan Philipp. 2011. Appeal and Sentence in International Criminal Law. Berlin: Berliner Wissenschafts-Verlag GmbH.

Bröstl, Alexander, Patrik Príbelský, Lucia Berdisová, Marta Breichová Lapčáková, Mária Kolíková, and Slavomír Trnkócy. 2010. Ústavné právo SR (Constitutional law of the Slovak republic). Plzeň: Vydavatelství a nakladatelství Aleš Čeněk.

Čentéš, Jozef. 2001. Právna úprava trestnej zodpovednosti v slovenskom právnom poriadku (Legal regulation of criminal liability in the Slovak legal order). Finančný Radca 1: 15-17.

Čentéš, Jozef. 2011. Účinná l'útost' pri daňových trestných činoch v SR a v ČR (Active repentance at tax offenses in the Slovak Republic and in the Czech Republic). In Nové jevy v hospodářské kriminalitě ve světle reformy trestniho práva (New Phenomena in Economic Crime in the Light of the Reform of Criminal Law). Brno: Masarykova univerzita v Brně.

Čentéš, Jozef, Martin Bargel, Radovan Blažek, Eduard Burda, Jaroslav Klátik, Marta Kolcunová, Juraj Kolesár, Marek Kordík, Lucia Kurilovská, Ondrej Laciak, and et al. 2012. Trestné právo procesné. Všeobecná a osobitná čast' (Criminal Procedure Law. General and Special Part). Šamorín: Heuréka.

Čič, Milan. 2013. Komentár k Ústave Slovenskej republiky (Commentary on the Constitution of the Slovak Republic). Bratislava: Eurokódex.

Domin, Marek. 2012. Zrušenie priestupkovej imunity a prezident Slovenskej republiky (Revocation of offence exemption and President of the Slovak Republic). Justičná Revue 64: 531-41.

Drgonec, Ján. 2006. Imunita ústavných činitel'ov v Slovenskej republike (Exemption of constitutional official in the Slovak Republic). Justičná Revue 58: 1127-45.

Drgonec, Ján. 2012. Ústava Slovenskej Republiky: Komentár (Constitution of the Slovak Republic: Commentary). Šamorín: Heureka.

Drgonec, Ján. 2013. Obžaloba na prezidenta SR vo svetle prvej skúsenosti (Indictment against the President of the Slovak Republic in the light of the first experience). Justičná Revue 65: 908-24.

Filip, Jan. 1997. Vybrané kapitoly ke studiu ústavního práva (Selected Chapters on the Study of Constitutional Law). Brno: Masarykova univerzita.

Filip, Jan. 2010. K ústavní odpovědnosti v ČR a odpovědnosti hlavy státu zejména za velezradu (On Constitutional Responsibility in the Czech Republic and the Responsibility of the Head of State in particular for treason. Časopis pro právní vědu a Praxi 18: 21-39. 
Gřivna, Tomáš. 2006. Imunity podle vnitrostátního práva z pohledu trestního práva (Immunities under national law from the point of view of criminal law). Trestněprávní Revue 5: 65-69.

Hanuliak, Juraj. 2009. Inštitút prezidenta v ústavnom a politickom systéme Litovskej republiky (President's Institute in the Constitutional and Political System of the Republic of Lithuania). Slovenská Politologická Revue 9: $107-28$.

Ivor, Jaroslav, Jaroslav Fenyk, Dušan Korgo, Darina Mašl'anyová, Peter Polák, and Jozef Záhora. 2010a. Trestné právo hmotné: 1: všeobecná čast' (Substantive Criminal Law: General Part). Bratislava: Iura Edition.

Ivor, Jaroslav, Jozef Čentéš, Jaroslav Fenyk, Dušan Korgo, Vladimír Mathern, Marek Mihálik, Štefan Minárik, Peter Polák, Jana Viktoryová, and Jozef Záhora. 2010b. Trestné Právo Procesné (Criminal Procedure Law). Bratislava: Iura Edition.

Klimek, Libor. 2015. European Arrest Warrant. Cham: Springer.

Majerčák, Tomáš. 2009. Imunita ústavných činitel'ov. Ústavný systém Slovenskej republiky (Exemption of Constitutional Officials. Constitutional System of the Slovak Republic). Košice: Univerzita Pavla Jozefa Šafárika.

Mencerová, Ingrid, Lýdia Tobiášová, Yvetta Turayová, Matúš Hut’ka, Michal Kačáni, Martin Krnáč, and Michal Valent. 2013. Trestné právo hmotné. Všeobecná čast' (Criminal Substantive Law. General Part). Šamorín: Heuréka.

Mihálik, Jaroslav. 2011. The Institution of Presidency in the Process of Democratic Transition in the Visegrad Group Countries-A Comparative Perspective: A Brief Introduction to the System Transformation. Kraków: Księgarnia akademicka.

Musil, Jan, Vladimír Kratochvíl, and Pavel Šámal. 2003. Kurs trestního práva: Trestní právo procesní (Course of Criminal Law: Criminal Procedural Law). Praha: C. H. Beck.

Orr, Alan. 2002. Treason and the State: Law, Politics and Ideology in the English Civil War. New York: Cambridge University Press.

Palúš, Igor, and L'udmila Somorová. 2010. Štátne Právo Slovenskej Republiky (State Law of the Slovak Republic). Košice: Univerzita Pavla Jozefa Šafárika.

Pavlíček, Václav. 2001. Ústavní právo a státověda. II. dil: Ústavní právo České republiky. Část 1 (Constitutional Law and State Science. II. Volume: Constitutional Law of the Czech Republic). Praha: Linde.

Safferling, C. 2012. International Criminal Procedure. Oxford: Oxford University Press.

Svák, Ján, and L'ubor Cibulka. 2013. Ústavné právo SR. Osobitná čast' (Constitutional Law of the Slovak Republic. Special Part). Bratislava: Eurokódex.

Večeřa, Miloš, Alex Gerloch, Hans Schlosser, Karel Beran, and Slavomír Rudenko. 2011. Teória práva (Theory of Law). Bratislava: EUROKÓDEX, s.r.o.

Yordanova, Maria. 2012. Right of Defence and the Principle of Equality of Arms in the Criminal Procedure in Bulgaria. Sofia: Center for the Study of Democracy.

Záhora, Jozef. 2005. Imunity a výsady v trestnom práve. Justičná Revue 57: 364-79.

(C) 2019 by the authors. Licensee MDPI, Basel, Switzerland. This article is an open access article distributed under the terms and conditions of the Creative Commons Attribution (CC BY) license (http://creativecommons.org/licenses/by/4.0/). 